Acta Theriologica 37 (4): 403 - 411, 1992.

PL ISSN $0001-7051$

\title{
Building activity of beavers
}

\author{
Wirgiliusz ŻUROWSKI
}

Zurowski W. 1992. Building activity of beavers. Acta theriol. 37: $403-411$.

Observations on the building activity of European beavers, Castor fiber Linnaeus, 1758 , were carried out in two dissimilar lakelands in Poland to which beavers were being reintroduced from 1974 to 1985 . Reintroduced beavers occupied 62 sites, and lodges were built in $76 \%$ of the sites. Several sites contained two or more lodges. Most lodges had a circular or oval base $(83 \%)$ and a conical side view $(85 \%)$. The size of lodges differed significantly $(p=0.051)$ between the two lakelands, with larger lodges at sites characterized by water scarcity. Beavers built lodges immediately after their settlement in $50 \%$ of sites, while in the other sites lodges appeared $1-8$ years later. Lodge construction is frequently related with the first appearance of kits. In the study area beavers built 27 dams in 17 sites, apparently to improve water conditions and to get safe access to new stores of winter food. Dams usually were built without acoustic stimuli. Behaviour of reintroduced beavers suggest threat as their main motivation for any building activity.

Research Station of Polish Academy of Sciences, 12-222 Wejsuny, Popielno, Poland

Key words: Castor fiber, lodge, dam, building behaviour, Poland

\section{Introduction}

Beavers have a unique ability to modify their environment by actively building dams, creating ponds, and building lodges. No other mammal has such a broad range of construction behaviour. Many scientists have studied the building activity of beavers. Hodgdon and Lancia (1983) reported that environmental conditions influenced building behaviour, as well as the type of construction (dam, lodge). Dams were built mainly on streams or small watercourses between ponds, but not on large rivers or lakes. According to these authors, beavers built dams preferably in places where the sound of water flowing over an obstruction can be heard, and audible stimuli are considered an important factor in triggering the impulse to build a dam. Wilsson (1971) studied different stimuli which trigger building behaviour in beavers. He maintains that their building activity is determined by season (highest in autumn), pregnancy, and the presence of young individuals. For example, an impulse to build a lodge is sparked when water rises in the burrow and submerges the nest. The lodge building behaviour activates an impulse to build a dam, and sounds of the water flow stimulate this impulse. Beavers dig burrows wherever banks are sufficiently high. If such shelters cannot be made, 
they build lodges in which they bore ditches and tunnels and make a vestibule and a chamber. A lodge under construction begins to be used as a shelter when its height over the chamber reaches about $1 \mathrm{~m}$ and its base is about $2 \mathrm{~m}$ in diameter. Wilsson (1971) devoted much attention in his studies to the development of building behaviour in beavers during their ontogenesis. Richard (1983) reported characteristic differences in building techniques between beavers and other mammals. He maintains that beavers are motivated to do constructions by some species-specific inborn mechanism. Audible stimuli matter a lot in triggering and steering the building behaviour of beavers. He offers detailed descriptions of building techniques for channels, burrows, lodges, and dams as well as of gathering the winter food. Aeschbacher and Pilleri (1983) carried out a comprehensive study on the beaver's lodge under construction: building techniques, selection of building materials, and translocation of building materials within the lodge. The data were obtained from Canadian beavers in captivity and compared with those provided by free-living European beavers. The authors reported that Canadian beavers carry out their constructive work individually and only a major incident, like damage to a dam or collapse of the roof of the lodge or burrow, induced the family to do the job together. Collective building behaviour is then observed until the repair is completed.

Reintroduction of the European beaver to lakelands of northern Poland after their absence for several centuries has offered a unique opportunity for observation of the building activity of beavers. The present paper reports the results of these observations and some views on this activity.

\section{Material and methods}

The studied material was collected in the southern part of the Masurian Lakeland $\left(53^{\circ} 38^{\prime}-\right.$ $\left.53^{\circ} 52^{\prime} \mathrm{N}, 21^{\circ} 07^{\prime}-22^{\circ} 00^{\prime} \mathrm{E}\right)$ and in the Brodnica Lakeland $\left(53^{\circ} 02^{\prime}-53^{\circ} 17^{\prime} \mathrm{N}, 19^{\circ} 23^{\prime}-19^{\circ} 37^{\prime} \mathrm{E}\right)$. In the Masurian Lakeland regions with typical lakeland forest-covered landscape, beavers were reintroduced from 1974 to 1985. In the Brodnica Lakeland beavers were released between 1976 and 1977, mainly near peat excavations and small lakes in agricultural areas.

Direct observations have been made at every site occupied by reintroduced animals or their offspring from 1974 to 1990 . Each beaver site was checked at least twice a year: in the spring and autumn, or several times if the building activity, change of place or delayed delivery (kitten) were recorded. Changes appearing in beaver sites were recorded in the form of a description, a drawing or a photograph. The longer diameter of the beaver lodge base and the height of the lodge above the water level were measured and shapes were recorded (Fig. 1). In late spring every site with a lodge was checked for the presence of youngs by tape-recording their sounds (Zurowski 1979). The controlled areas and quality of water bodies were well known to the present writer. Before reintroduction and from 1987 to 1989 , both areas were carefully evaluated for the choice of reintroduction places to estimate the prospects of future beaver populations. All places favourable for beavers (i.e., quality of water and store of winter food) were described. The study includes data from those sites only in which beavers built lodges and dams. Sites with only burrows and channels were omitted. 


\section{Results}

In both lake districts there were 62 sites, 47 in the Masurian and 15 in the Brodnica Lakeland. In late 1989 there were 34 sites with lodges and 17 sites with dams (Table 1). The total number of lodges was higher than the number of beaver sites because some sites contained two or more lodges. Additional lodges, which were built 20 to $300 \mathrm{~m}$ apart, were used by beavers in different ways depending on the topography of the site. Most often they were utilized as an extra shelter for the family during summer nights. In a few cases females gave birth to kits and reared them for some time in the secondary lodges (Table 2). In winter these lodges were sometimes used instead of the main ones, especially when water level was low near the main lodge. The use of secondary lodges in winter was observed repeatedly at two sites (Table 2). In both sites beavers moved to the secondary lodges where water was deep enough to hold a store of winter food. In winter time those areas were not visited by people. However, in summer, recreation camps were situated nearby and in the spring beavers moved back to their main lodges. At the primary lodge water was too shallow to hold any food stores, but the locations were remote and not affected by human activity. No regular pattern of movement to the winter lodge was observed. Occasionally a newly formed family would stay in a secondary lodge and rear offspring. Such cases were observed in sites situated among fields in the Brodnica Lakeland during dry years when beavers did not wander.

It was observed three times that two lodges had been built so close to each other that they had formed practically one lodge for the family. Such lodge conjunction was counted as one lodge and its summed dimensions were given in lodge characteristics. Table 3 presents sizes of 40 lodges from the Masurian Lakeland and 13 lodges from the Brodnica Lakeland. While in use, the beaver lodge may change shape since very often it is erected on a wet, peaty soil intersected with beaver channels so that it subsides in the course of year. A lodge is systematically enlarged and reconstructed, especially in late autumn, in preparation for winter, and often in the spring. However, in the spring several examined lodges were not reconstructed. I never recorded kits in these lodges.

Table 1. Numbers of beaver sites and sites with lodges in the investigated lakelands.

\begin{tabular}{|c|c|c|c|c|c|c|c|c|c|c|}
\hline \multirow{4}{*}{ Lakeland } & \multirow{4}{*}{$\begin{array}{c}\text { Total } \\
\text { no. of } \\
\text { sites }\end{array}$} & \multicolumn{9}{|c|}{ Sites with lodges } \\
\hline & & \multirow{3}{*}{ Sites } & \multirow{3}{*}{ Lodges } & \multirow{3}{*}{$\begin{array}{l}\text { Lodges } \\
\text { per site }\end{array}$} & \multicolumn{2}{|c|}{$\begin{array}{l}\text { Occupied in the fall } \\
\text { of } 1989\end{array}$} & \multicolumn{4}{|c|}{ Vacated or destroyed } \\
\hline & & & & & \multirow{2}{*}{$\begin{array}{c}\text { Sites } \\
\mathrm{n}\end{array}$} & \multirow{2}{*}{$\begin{array}{l}\text { Lodges } \\
\text { n }\end{array}$} & \multicolumn{2}{|c|}{ Sites } & \multicolumn{2}{|c|}{ Lodges } \\
\hline & & & & & & & $\mathrm{n}$ & $\%$ & $\mathrm{n}$ & $\%$ \\
\hline Masurian & 47 & 35 & 41 & 1.17 & 25 & 29 & 10 & 29 & 12 & 29 \\
\hline Brodnica & 15 & 12 & 15 & 1.25 & 9 & 11 & 3 & 25 & 4 & 27 \\
\hline Total & 62 & 47 & 56 & 1.19 & 34 & 40 & 13 & 28 & 16 & 28 \\
\hline
\end{tabular}


Table 2. Different quantity observations of beaver behaviour in the Masurian and Brodnica Lakelands in $1974-1990$.

No. Specification of beaver behaviour

1 Birth in the additional lodges

2 Alternate lodges used in the winter time

3 Larger lodges built

4 Double lodges built

5 Vanishing of abandoned lodges

6 Resettled (abandoned) lodges

$7 \quad 3-8$ year delays in lodge building

8 Lodge building connected with the first kitten

9 Dam building for access to new areas for winter food
Recorded

Beaver site location

8

Sniardwy Lake $2 x$

Lawny Lasek $3 x$

Zdrużno Lake $3 x$

$9 \quad$ Lawny Lasek $5 \times$

Zdrużno Lake $4 x$

5 Marak I Marsh

Marak II Marsh

Kotowy I Marsh

Kotowy II Marsh

Skrwilno Lake

3 Marak II Marsh

Księte Lake

Babięcka River

9 Sniardwy Lake 4 lodg.

Tejsowo Lake

Blankowa River I

Gant River I

Tuchlin Lake

Zatorowizna Brook

2 Blankowa River I

Snopki Marsh

4 Snopki Marsh

Kujno Lake

Spychowo River

Krutynia River I

$9 \quad$ Skrwilno Lake

Marak II Marsh

Księte Lake

Karwik Lake

Snopki Marsh

Klarewo Marsh

Sniardwy Lake I

Blankowa River I

Blankowa River II

5 Ławny Lasek Irrig. syst.

Osa Marsh

Powałczyn Brook

Blankowa River II $3 \times$

Blankowa River III

1 Księte Lake, estuary 
Table 3. Characteristics of beaver lodges. * The difference between Masurian and Brodnica tested by Student $t$-test is significant at $p=0.05$.

\begin{tabular}{|c|c|c|c|c|c|c|c|c|c|c|c|c|c|c|c|}
\hline \multirow{4}{*}{ Lakeland } & \multirow{4}{*}{$\begin{array}{c}\text { Total } \\
\text { no. of } \\
\text { lodges }\end{array}$} & \multicolumn{8}{|c|}{ Shape of lodge } & \multicolumn{6}{|c|}{ Average size of lodge (m) } \\
\hline & & \multicolumn{4}{|c|}{ Base } & \multicolumn{4}{|c|}{ Side view } & \multirow{2}{*}{\multicolumn{2}{|c|}{ Height }} & \multirow{2}{*}{\multicolumn{2}{|c|}{ Lenght }} & \multirow{2}{*}{\multicolumn{2}{|c|}{$\begin{array}{l}\text { Heigth } \\
+ \text { length }\end{array}$}} \\
\hline & & \multicolumn{2}{|c|}{ Circual or oval } & \multicolumn{2}{|c|}{ Other } & \multicolumn{2}{|c|}{ Coniform } & \multicolumn{2}{|c|}{ Other } & & & & & & \\
\hline & & $\mathrm{n}$ & $\%$ & $\mathrm{n}$ & $\%$ & $\mathrm{n}$ & $\%$ & $\mathrm{n}$ & $\%$ & $\bar{x}$ & SD & $\bar{x}$ & SD & $\bar{x}$ & SD \\
\hline Masurian & 40 & 37 & 92 & 3 & 8 & 36 & 90 & 4 & 10 & 1.6 & 0.5 & 4.8 & 2.0 & 6.0 & 2.4 \\
\hline Brodnica & 13 & 7 & 54 & 6 & 46 & 9 & 69 & 4 & 31 & 2.0 & 0.6 & 7.8 & 4.9 & $9.7^{*}$ & 5.7 \\
\hline Total & 53 & 44 & 83 & 9 & 17 & 45 & 85 & 8 & 15 & 1.7 & 0.6 & 5.5 & 3.3 & 7.2 & 3.8 \\
\hline
\end{tabular}

Table 4. Start time of lodge construction in a new beaver site.

\begin{tabular}{lccccc}
\hline \multirow{3}{*}{ Number of sites } & \multicolumn{4}{c}{ Start of lodge building } & \multirow{2}{*}{ Total } \\
\cline { 2 - 5 } & At once & $\begin{array}{c}\text { Within the } \\
\text { 1st year }\end{array}$ & $\begin{array}{c}\text { Within the } \\
\text { 2nd year }\end{array}$ & $\begin{array}{c}\text { Within the } \\
3-8 \text { years }\end{array}$ & \\
\hline $\mathrm{n}$ & 23 & 11 & 9 & 4 & 47 \\
$\%$ & 49 & 23 & 19 & 9 & 100 \\
\hline
\end{tabular}

This is why the size and shape of a beaver lodge may change from year to year. Usually, the shape is conical with a circular or oval base ( $83 \%$ of the studied beaver lodges). Lodges erected on the waterside most often have an oval base with the longer diameter oriented towards the water. Lodges with bases shaped differently (Fig. 1) are rarely constructed (17\%). Their shape resulted usually from the topography where the beavers started to build (e.g. a dyke between peat excavations) and also as a stage of lodge construction. In a site on the Krawno Lake the base of a lodge was semicircular in shape in the first few years but later it became oval. At a site situated near the Gant Lake a lodge had a large conic form with a slighty broadened summit for the first five years, which collapsed during the winter of 1986 . Beavers reconstructed this lodge in the form of an irregular body, and in 1989 its base resembled three fingers widely spread. Lodges different in shape from a circle or oval usually have a nonconical side view. Quite often in large lodges there is a vestibule serving as refectory in the form of a raised peak. The side view of such a lodge resembles a summit with an additional hill while the base is oval.

Data for beaver lodges presented in Table 3 include objects utilized by beavers in 1989 and those measured after their abandonment by beavers. These are rather tentative data, but they may be useful for comparisons. Each successive year may result in a lodge of a different size, but in the Brodnica Lakeland larger lodges than in other areas have been recorded since 1978. The sizes of beaver lodges 
A

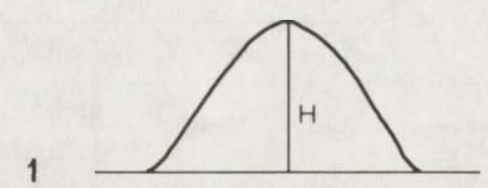

1

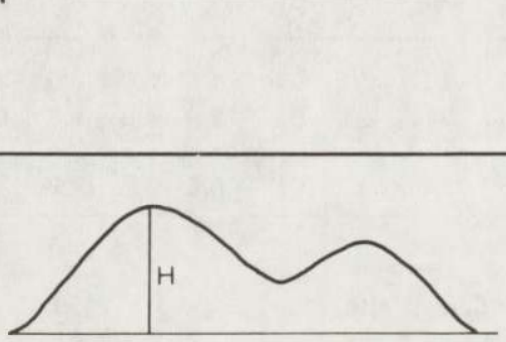

2
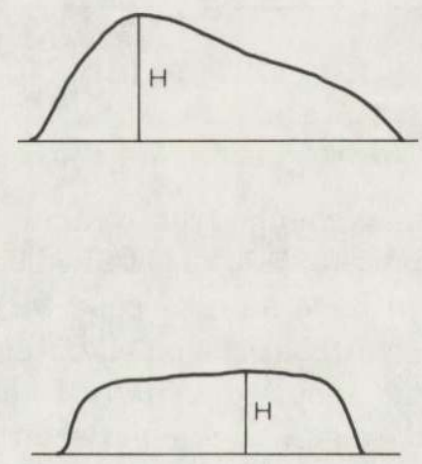

B
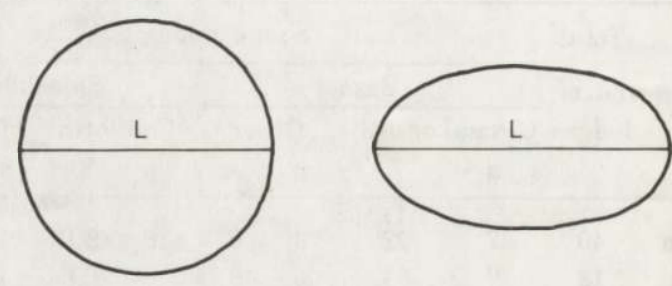
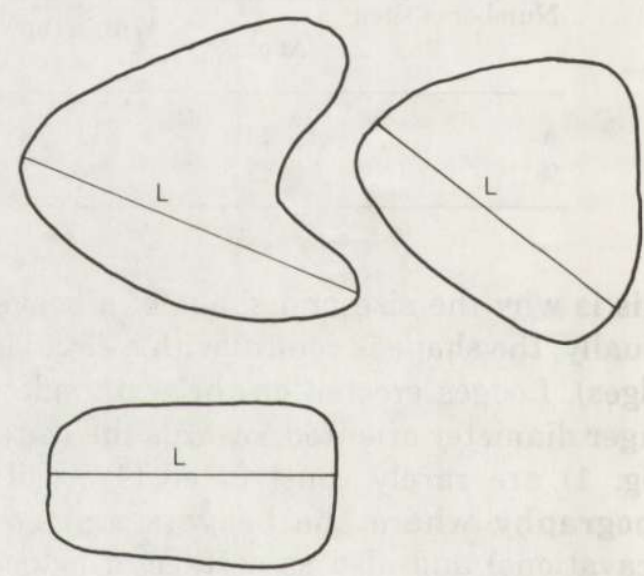

Fig. 1. The most frequently observed forms of European beaver lodges. A - side view, B - base view, $\mathrm{H}$ - height, L - length, 1 - the most usual conical form with circular or oval view of the base, 2 other forms of lodges.

were as follows: height ranged from 0.6 to $3.5 \mathrm{~m}$, and the longer diameter of the lodge base ranged from 2 to $20 \mathrm{~m}$. Data for lodge sizes suggest a significant difference $(p=0.05)$ between the two studied lakelands. Visibly larger lodges are found at the Brodnica Lakeland. Perhaps it is exclusively due to natural conditions characterized by water scarcity and periodic drying of peat excavation in the summer: 1982, 1983, 1984, 1989, and 1990. In this lakeland, periodic water deficiency mobilized beavers to build larger lodges and numerous channels to protect themselves from predators like dogs and otters. 
Vacated beaver lodges go to ruin and not a trace is left of even a large lodge within $2-3$ years after their departure. However, such large lodges vacated for a year or so may be resettled by new beavers or by the former dwellers whose new residence was destroyed by people. In such cases the newcomers rapidly reconstructed the lodge.

Observations on the effects of the reintroduction of beavers into the studied areas suggest that a lodge is not neccessarily built just after acceptance of the site by beavers. In newly settled sites beavers started to build a house in only $50 \%$ of the cases. In the other sites, lodges were built from 1 to 8 years after settlement (Table 4). The tape-recorder monitoring for the presence of kits carried out every May and June as well as direct observations of the studied sites have revealed that frequently it is the birth of kits that stimulates the animals to build a lodge (Table 2). For example a single beaver had lived for 6 years in shallow and frequently subsiding burrows in the peat dyke along peat pond. In 1987 another beaver came to that site. On May 20th, 1988 voices of four kits were tape-recorded. In autumn the beavers built a lodge.

In a beaver lodge there is usually one habitable chamber, as has been confirmed by systematic monitoring every year for the presence of kits with the use of the tape-recorder. Even in very large beaver lodges kits voices were always recorded from the same chamber (recorded several times in the two lodges: Kotowy Marsh I, and Skrwilno Lake).

At both studied lakelands, 27 beaver dams were recorded in 17 sites. Of these, 6 sites and 9 dams were on small rivers, while the other 11 sites and 18 dams were on drainage ditches. Water flow was rapid in only one site, where stones in the river generated distinct sounds of flowing water. During autumn beavers repeatedly tried to build a dam near this location, however, anglers, destroyed the construction. In all other sites where beavers built dams in brooks as well as in drainage ditches water flow was very slow. Those sites were situated in flat lowlands and in none of them water flow was audible to humans. Water sounds appeared only where a beaver dam had existed before. During frequent examinations of the down-run of Krutynia river where there were several beaver sites, a lot of places with water sounds were found (ruts, branches and other obstacles). I never discovered beaver dam building activity there. The river is about $5-10$ $\mathrm{m}$ wide, more than $1 \mathrm{~m}$ deep and the banks are rich with beaver winter food, mainly willows. Each time beavers built a dam to improve the water abundance in their site. In five sites the dam building seemed to be related to safe access to new areas of winter food (Table 2).

Blankowa Struga is a brook flowing through forests; its banks do not abound with beavers, favourite winter food. There are beaver sites: one in the upper section of the river, and the other $2 \mathrm{~km}$ away near the estuary into the lake. Dams were built in both sites and beaver ponds with lodges over them appeared. When winter food near the ponds had been exhausted, beavers from both sites built another dam a few dozen meters downstream, and pools that were formed gave beavers 
access to new areas with winter food. In the site at the estuary, rapid water flows in the spring repeatedly washed out this poorly maintained dam. The beavers reconstructed it three times during intense autumn feedings, but twice it was not erected in the same place. In the vicinity of the additional dam beavers intensively cut deciduous trees and transported branches upstream through the main dam to the store of winter food.

In most cases, particulary if raised on drainage ditches, the dams are systematically destroyed by farmers. Quite frequently the dams are reconstructed by beavers in autumn; the presence of dams made water more abundant in winter time for beavers. In the studied lakelands, in only 7 sites (out of the 17) dams were not destroyed by people. These were sites situated far into unutilized marshes or on brooks flowing through forest.

\section{Discussion}

When coming to a new site, beavers started to built a lodge at once if there had been no other possibility for them to get a shelter in the place. That was the case with low-lying marshy terrains where beavers could not dig burrows or find another hiding place. Single beavers or kitless pairs could live many years in shallow burrows. Every older beaver belonging to the family has a highly developed protective instinct (Patenaude 1983). Frequently the beavers dwelling in a flimsy shelter start building a solid and safe lodge once kits are born. Spring renovating and strengthening of the lodge were also frequently connected with expansion of the new generations. The studies reported here confirm observations of Wilsson (1971) and Richard (1983) that construction and renovation of beaver lodges are frequently connected with their reproduction. The building of larger lodges was connected with the scarcity of water. The same holds true for building the dams. This job has to be done to improve water abundance at the site. For it is in water where beavers are safe due to their anatomical and physiological adaptations. Each time we took a beaver by suprise on the land it would run away towards a body of water or a stream. It would never try to find any hiding place on the land. With beaver dams and ponds the site becomes much safer. This is clear enough when considering the cases of raising additional dams by beavers to have an area with winter food. Also in mountainous regions where streams are narrow and shallow, beavers build a cascade system of dams (Zurowski 1989) for safety and to get access to larger feeding areas. It seems improbable that any audible stimuli matter in this case, for sounds of flowing water are generated in the mountainous streams almost everywhere. In lowlands, in most cases dams seem to be built independently of audible stimuli. Beavers do not build dams on the bigger rivers with banks rich with winter food, in spite of water sound (audible stimuli). Sounds of flowing water believed by Wilsson (1971), Richard (1983) and Hodgdon and Lancia (1983) to provoke dam building may be a secondary reaction connected with the character of the place. Such sounds may carry information for beavers 
about dam damage. Then, the building activity of a beaver family in response to these stimuli is of the same nature as that observed by Aeschbacher and Pilleri (1983) in response to the collapse of a lodge wall. It would be, however, a reaction to an unusual situation as shown by Hartman (1975). He reported on a young beaver kept under artificial, experimental conditions; it had responded with a flight to another, safer den when exposed to experimental sounds of water flow. Such sounds were strange for this beaver and they never provokes any building behaviour.

The presented observations suggest that the main factor motivating beavers to any building activity is safety, although in specific situations local water sound also provoke dam building.

Editor's acknowledgements. Professor W. Zurowski passed away on July 24th 1992 . He left the manuscript of this paper not definitively revised. It was decided that it be published with some minor editorial corrections. Thanks are due to Professor Z. Jaczewski and B. Kasperczyk for taking care of this manuscript. This work was supported by RR-II.17 Project, coordinated by the Academy of Agriculture, Poznań.

\section{Reference}

Aeschbacher A. and Pilleri G. 1983. Observations on the building behaviour of the Canadian beaver (Castor canadensis) in captivity. [In: Investigation on beavers. G. Pilleri, ed.]. Brain Anatomy Institute, Berne, 1: $83-98$.

Hartman A. M. 1975. Analysis of conditions leading to the regulation of water flow by a beaver. Psychol. Rec. 25: $427-431$.

Hodgdon H. E. and Lancia R. A. 1983. Behaviour of the North America beaver Castor canadensis. Acta zool. fenn. 174: $99-103$.

Patenaude F. 1983. Care of the young in a family of wild beavers Castor canadensis. Acta zool. fenn. 174: $121-122$.

Richard P. B. 1983. Mechanisms and adaptation in the constructive behaviour of the beaver (C. fiber L.). Acta zool. fenn. 174: $105-108$.

Wilsson L. 1971. Observations and experiments on the ethology of the European beaver (Castor fiber L.). Viltrevy 8, 3: $1-266$.

Zurowski W. 1979. Preliminary results of European beaver reintroduction in the tributary stream of the Vistula river. Acta theriol. 24: $81-87$.

Zurowski W. 1989. Dam building activity of beavers on the moutainous streams. Vth ITC, Abstracts of papers and posters. Rome 1: $316-317$.

Received 22 April 1991, revised 2 September 1992, accepted 1 October 1992. 